\title{
Orthokeratinized odontogenic cyst: A report of two cases in the mandible
}

\section{Cisto odontogênico ortoqueratinizado: relato de dois casos em mandíbula}

\begin{abstract}
Purpose: To describe the behavior clinical and pathological features of two cases of odontogenic cyst orthokeratinized.

Case description: In case 1, a 17-year-old woman presented hard and painless swelling in the left posterior mandible. Radiographically, a radiolucent area with a radiopaque was observed. A clinical diagnosis of ameloblastoma or odontogenic keratocystic tumor was established. The histopathological examination revealed an orthokeratinized odontogenic cyst. In case 2, a 23-year-old woman presented a radiolucent lesion surrounded by radiopaque halo symmetrically distributed on both partially erupted lower third molars. A clinical diagnosis of bilateral dentigerous cyst (DC) was rended. The histopathological examination showed bilateral orthokeratinized odontogenic cyst.

Conclusion: Orthokeratinized odontogenic cyst should be considered in the differential diagnosis of lesions occurring in the jawbones associated with an impacted tooth, particularly those cases simulating dentigerous cyst. In addition, we observed the importance of radiographs taken prior to orthodontic treatment as an important tool in the diagnosis of oral pathologies. Performing routine radiograph is of high clinical value, especially before orthodontic treatment.
\end{abstract}

Key words: Odontogenic cysts; jaw cysts; nonodontogenic cysts

\section{Resumo}

Objetivo: Descrever os aspectos clinicopatológicos de dois casos de cisto odontogênico ortoqueratinizado e a compará-los a relatos anteriores.

Relato do caso: No caso 1, uma mulher de 17 anos de idade, apresentou edema endurecido e indolor na mandíbula posterior esquerda. Radiograficamente, uma área radiolúcida com uma radiopacidade foi observada. O diagnóstico clínico de ameloblastoma ou tumor odontogênico ceratocístico foi estabelecido. O exame histopatológico revelou um cisto odontogênico ortoqueratinizado. No caso 2, uma mulher de 23 anos apresentou duas lesões radiolúcidas circundadas por halos radiopacos simetricamente distribuídas, associada aos terceiros molares inferiores irrompidos. Um diagnóstico clínico de cisto dentígero bilateral (DC) foi estabelecido. O exame histopatológico mostrou ser um cisto odontogênico ortoqueratinizado.

Conclusão: Cisto odontogênico ortoqueratinizado deve ser considerado no diagnóstico diferencial das lesões que ocorrem na mandíbula associado com dentes impactados, especialmente aqueles casos que simulem o cisto dentígero. Além disso, observamos a importância de tomadas radiográficas antes do tratamento ortodôntico no diagnóstico de patologias bucais.

Palavras-chave: Cistos odontogênicos; cistos maxilomandibulares; cistos não-odontogênicos

\author{
Francisco de Assis Caldas Pereira a \\ Manuela Torres Andion Vidal a \\ Paulo Sérgio Flores Campos b \\ Alberto de Aguiar Pires Valença Neto ${ }^{c}$ \\ Lúcio Costa Safira Andrade c \\ Alex Fernandes ${ }^{c}$ \\ Jean Nunes dos Santos a
}

\begin{abstract}
- Laboratory of Oral Surgical Pathology, School of Dentistry, Federal University of Bahia, Salvador, BA, Brazil

${ }^{b}$ Division of Oral and Maxillofacial Radiology, School of Dentistry, Federal University of Bahia, Salvador, BA, Brazil

c Division of Oral and Maxillofacial Surgery, School of Dentistry, Federal University of Bahia, Salvador, BA, Brazil
\end{abstract}

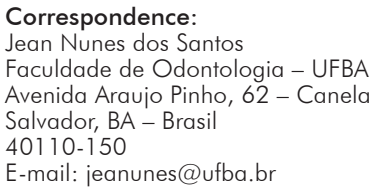

Conflict of Interests: The authors state that there are no financial and personal conflicts of interest that could have inappropriately influenced their work.

Copyright: (C) 2011 Pereira et al.; licensee EDIPUCRS This is an Open Access article distributed under the terms of the Creative Commons AttributionNoncommercial-No Derivative Works 3.0 Unported License. 


\section{Introduction}

The term Odontogenic Keratocystic (OK) was first introduced by Philipsen in 1956 to describe a particular pathological entity characterized by a fibrous cystic wall lined by keratinized epithelium. Thus, all cystic lesions of the jaws that had aspects of odontogenic keratocysts were considered, regardless of the clinical and other histological features (1-4). Currently, significant differences between keratinized cystic lesions are recognized and orthokeratinized odontogenic cyst (OOC) is no longer part of the spectrum of odontogenic keratocyst $(3,5-7)$.

Orthokeratinized odontogenic cyst (OOC) is a relatively rare lesion of the jaws, mainly located in the posterior segment of the mandible $(1,3)$. Clinically, it presents no tendency to relapse due to low local aggressiveness, and is not associated with the nevoid basal cell carcinoma syndrome (NBCCS) $(2,4,6)$. Radiographically they are presented as an unilocular radiolucent lesions with well defined margins $(2,3)$. Histologically, it is represented by a fibrous cystic wall lined by an orthokeratinized epithelium with thick keratinization, displaying a well-developed stratum granulosum and a defined layer of basal cells showing no tendency to palisade (1-5). The authors report two cases of OOC in young adults, comparing them with previous studies.

\section{Case description}

Case report 1

A 17-year-old woman was referred to the School of Dentistry of Federal University of Bahia, in Salvador, BA, Brazil, due to a hard and painless swelling in the left posterior mandible. The patient had noticed this swelling in the region about six months before. On palpation, the region corresponding to the lesion was located in the premolar region, extending into the molar region, and was covered by normal mucosa. Radiographically, a radiolucent area with a radiopaque halo causing divergence between the roots of the premolars was found (Fig. 1). Thus, a clinical diagnosis of ameloblastoma or odontogenic keratocystic tumor was established. Initially, an incisional biopsy was scheduled, but because of a great cleavage plane presented in the surgery, the lesion was completely enucleated. The specimen was sent for histopathological examination, that revealed a orthokeratinized odontogenic cyst, measuring $2,5 \times 1,5 \times 0,6$ $\mathrm{cm}$. This case also showed calcification and epithelial remnants scattered in the fibrous wall (Fig. 2). After surgery, the patient was followed up for a period of ten months, observing signs of bone healing at the injury site (Fig. 3).

\section{Case report 2}

A 23-year-old woman was referred to School of Dentistry of Federal University of Bahia for orthodontic treatment. However, on a routine panoramic radiography, radiolucent lesions surrounded by radiopaque halo were symmetrically found to be distributed on both partially erupted lower

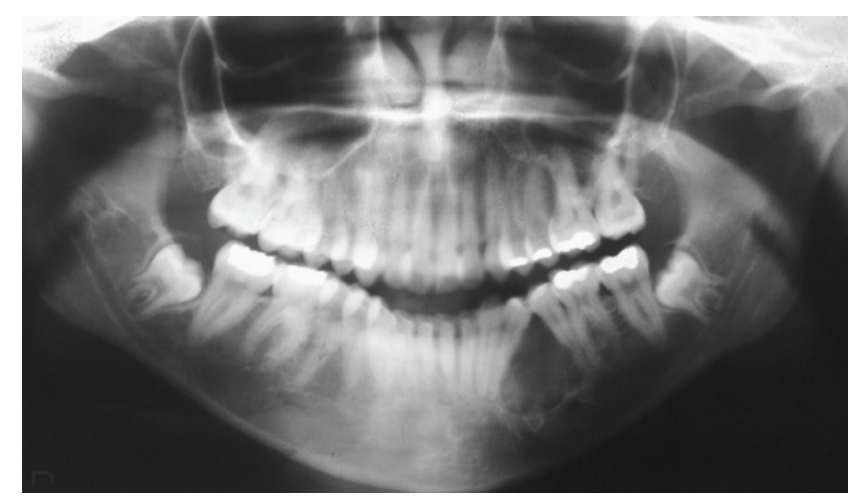

Fig. 1. Panoramic radiograph displaying a cystic lesion provoking divergence of the lower left premolar roots.

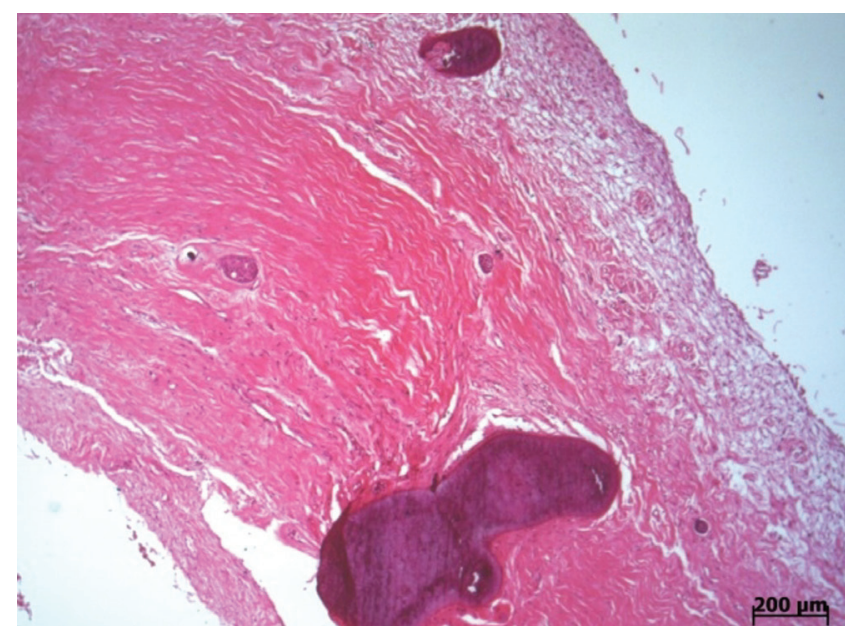

Fig. 2. Photomicrography of case 1 showing calcification scattered in the fibrous cystic wall.

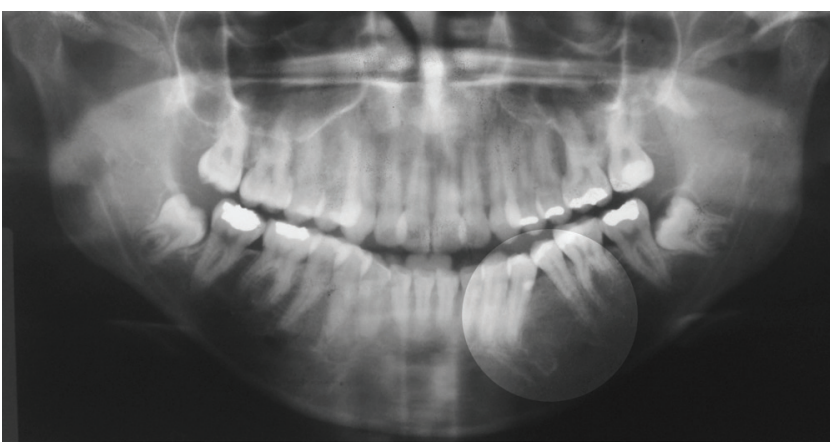

Fig. 3. Detail on panoramic radiograph showing bone healing after a follow-up period of 27 months.

third molars. Computerized tomography (CT), axial view and bone window, showed unilocular lesions bilaterally in the posterior region of the mandible. The lesion on the right displayed a slightly irregular contour and not always corticated margins. To the left, the lesion exhibited regular contour and living cortical outline. Interestingly, despite extensive thinning of cortical bone, the lesions promoted a mild buccolingual distention (Fig. 4). On CT dental arch 
reconstruction, bone window, to the right side we observed a partially erupted third molar in a horizontal position and slightly downwards to anterior, revealing unicystic injury associated with its crown. This lesion, which extended to the base of the mandible, showed irregular and occasionally corticated margins (above mentioned characteristics) and did not cause tooth displacement or root resorption. On the left, a partially erupted third molar, angled to mesial, showed unicystic injury associated with its crown, extending to the base of the mandible, exhibiting regular contour and corticated margins, and not causing displacement or important dental root resorption (Fig. 5). On physical examination, there were no signs of swelling in that region, and the mucosa and cortical bone remained intact. A clinical diagnosis of bilateral dentigerous cyst (DC) was rended. Afterwards, a biopsy was performed in both lesions, and specimens were sent for histopathological examination that showed bilateral orthokeratinized odontogenic cysts (Fig. 6), measuring $1,5 \times 1,0 \times 05 \mathrm{~cm}$ and $1,3 \times 0,8 \times 0,3 \mathrm{~cm}$ each. Both lesions were enucleated followed by third molars removals. The patient did not show evidence of recurrence for a period of 27 months.

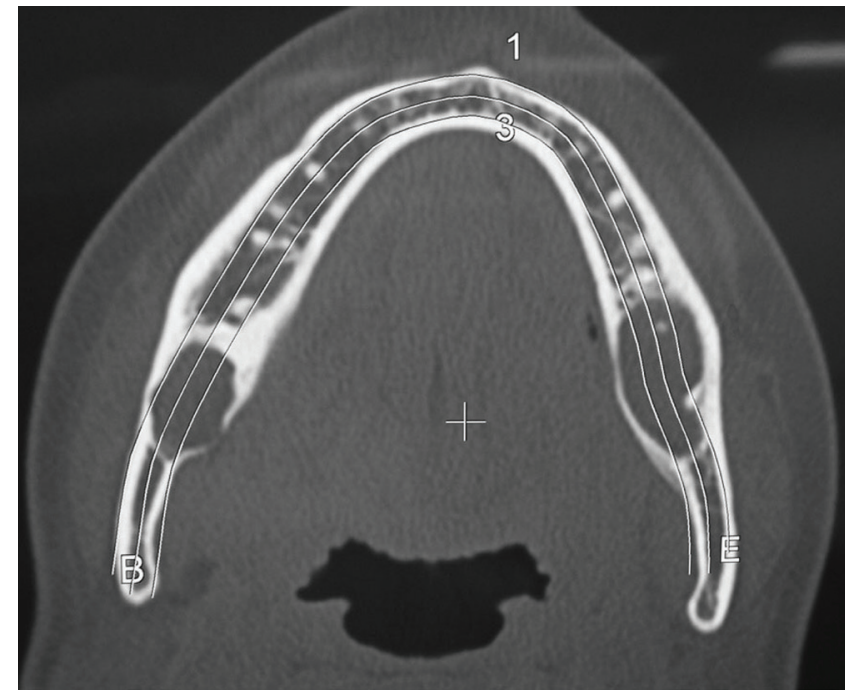

Fig. 4. Computerized tomography, axial view and bone window, showing unilocular lesions bilaterally in the posterior region of the mandible.

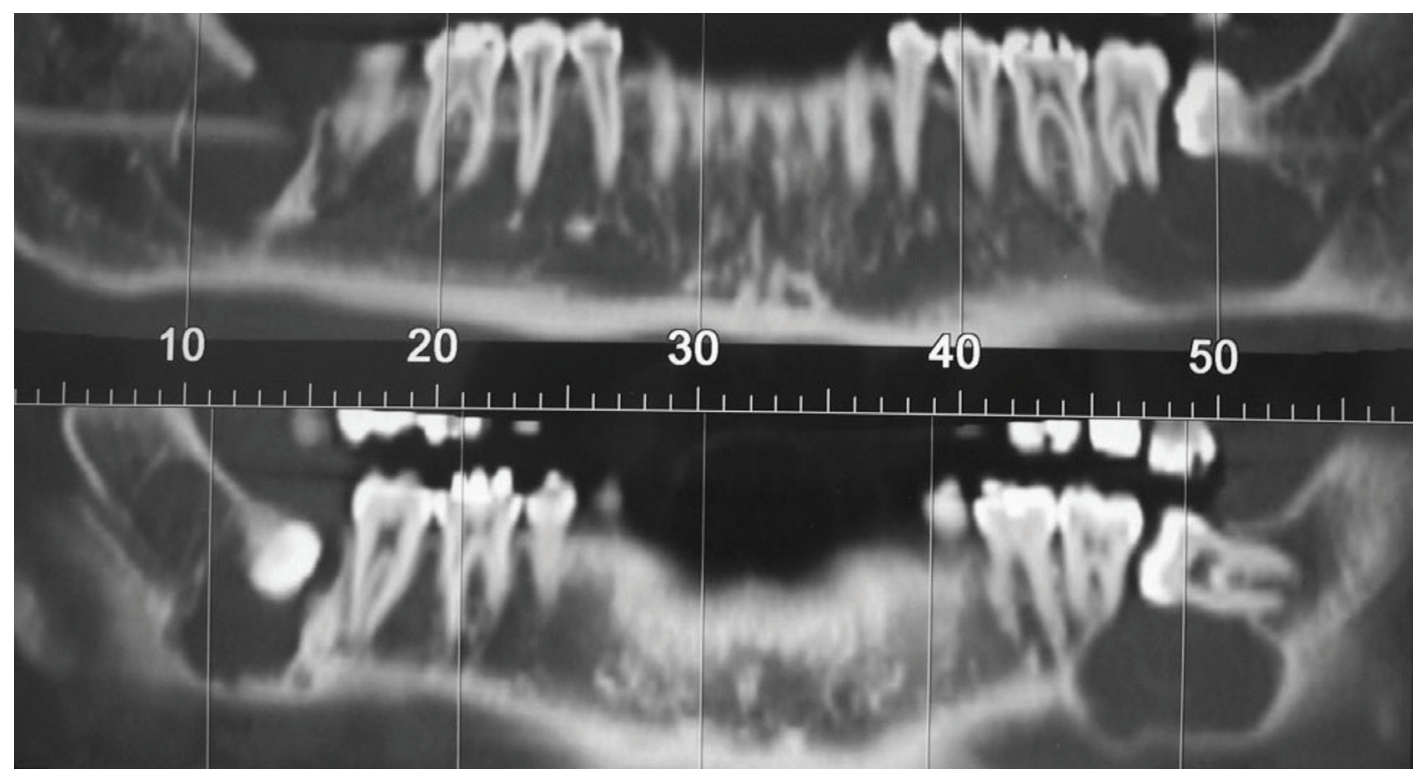

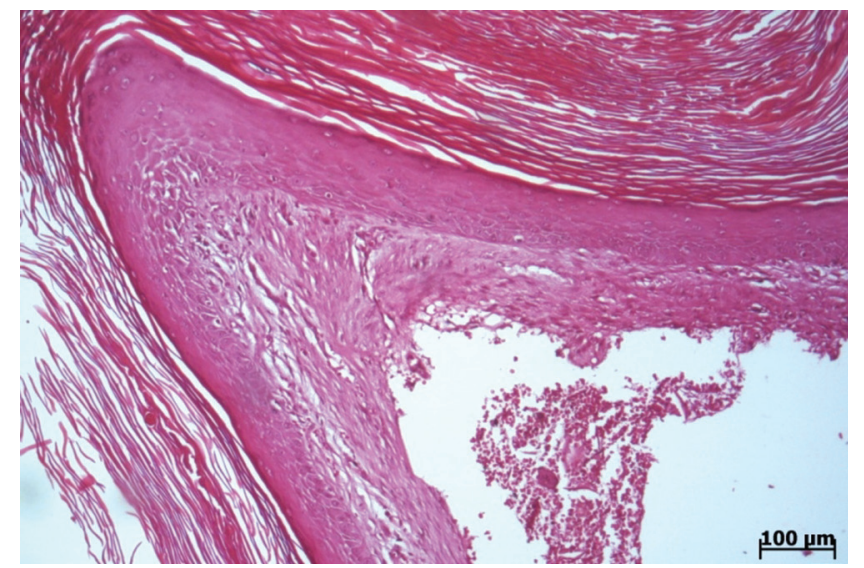

Fig. 5. Computerized tomography, dental arch reconstruction, bone window, exhibiting both lesions.
Fig. 6. Photomicrography of case 2 showing fibrous wall cystic covered by hyperkeratinized epithelium exhibiting proeminent granulosum layer. 


\section{Discussion}

Originally, the orthokeratinized odontogenic cyst (OOC) was described as a variant of odontogenic keratocyst (OK). However, both lesions show biological characteristics which are sufficiently distinct to recognize them as specific pathological entities $(2-4,6,7)$. Thus, OOC represents a very particular developmental odontogenic cyst (2), whereas the OK was recently included in the group of odontogenic tumors by the World Health Organization, named as keratocystic odontogenic tumor (KOT) $(5,6,8-10)$.

Odontogenic cysts with orthokeratinized epithelium are uncommon. According to Li et al. (2), the incidence varies from 5.2 to $16.8 \%$ between series, including cases previously diagnosed as odontogenic keratocysts. They represent approximately $11 \%$ of all cystic lesions of the jaws $(8,10)$. It is difficult to determine the prevalence of these lesions, as the criteria used to characterize them are not standardized among different studies $(1,2,10)$.

Dong et al. (11) in a recent review showed that females were more frequently affected than males (ratio 2.59:1). Both cases presented here affected young adult female; this finding is consistent with previous reports that show a predilection for young adults (1-3). However, it differs from other reports that show no significant sex predilection $(1,3)$. Li et al. (2) have shown greater preference for males.

According to previous studies, OOC more often affects the mandible, especially its posterior region, as observed in this study (1-3). However, in a particular case of this study, there was a rare bilateral involvement of orthokeratinized odontogenic cyst in the posterior mandible associated with the crowns of partially erupted third molars, whose initial clinical diagnosis was bilateral dentigerous cyst. According to several authors, OOCs are commonly associated with impacted teeth, and are generally diagnosed as dentigerous cysts (DCs) $(3,4,7,11)$. The dentigerous cyst is a classic form of developmental odontogenic cyst, affecting more frequently young patients, and generally arises as a single and totally asymptomatic small lesion, similar to what is seen in OOC $(1,12)$. In contrast, the KOT displays a locally aggressive behavior associated with significant rates of recurrence, as well as the NBCCS $(4,10,15)$. Despite these differences, Li et al (2) observed that nearly half the cases of OOC in their study had previously been diagnosed as ameloblastoma or odontogenic keratocyst tumor. The former diagnosis was attributed to one case of this study.

According Li et al. (2) and Vuhahula et al. (3), OOCs associated with impacted teeth may represent true dentigerous cysts with orthokeratinization, due to the pluripotency of odontogenic cystic epithelium, which is capable of inducing proliferation of orthokeratinized epithelium on the surface of a DC. Furthermore, orthokeratinized epithelial lining can be seen in other cysts affecting the maxillofacial region as dermoid/epidermoid cysts, even odontogenic keratocyst $(3,13)$.

Histopathologically, the cases of this study fulfill the morphological criteria that define the $\operatorname{COO}(2-4,7,10)$. The epithelial lining of both of orthokeratinized odontogenic cyst was thin and uniform epithelium, and the basal layer was less developed, with its cells displaying a cuboidal aspect without evidence of palisade, or nuclear polarization and hyperchromatism, which are characteristics of the odontogenic keratocystic tumor $(3,4,7,8)$. Li et al. (2) also described the presence of odontogenic epithelial remnants in OOC. However, we have not found previous reports about the presence of dystrophic calcification in this cyst as seen on case 1 .

Radiographies are constantly required prior to orthodontic therapy, as they provide a comprehensive view of the jaw bones, with minimal distortion and overlapping images (14,15). According Bondermark et al. (15), pretreatment orthodontic radiographs represent an important source for detecting abnormalities and diseases in the maxillomandibular region. In the present study, unilocular radiolucencies, associated with bilaterally impacted third molars were diagnosed from radiographic examinations performed with orthodontic purpose. Therefore, OOC should be taken into account in the differential diagnosis of radiolucencies associated with an impacted tooth. It is important to state that although unilocular radiolucencies with well defined margins represent a classical radiographic pattern, multilocular radiolucencies also may be found less frequently (11).

KOT is locally invasive and should be treated radically, through peripheral ostectomy, chemical curettage or block resection $(8,10)$. In a recent review, Madras and Lapointe (8) observed that the use of more aggressive therapeutic modalities, such as block resection, are associated with lower recurrence rates. In contrast, the OOC is treated in a conservative manner, performing only the enucleation of the lesion, as observed in both cases of this study. This form of treatment shows very satisfactory results, observing a relapse rate of only $2.2 \%$ of all cases $(2,5,7,10)$.

Over a 10-years period (2001-2010), from 1,924 cases referred to the Laboratory of Oral Surgical Pathology at the School of Dentistry, Federal University of Bahia, 75 keratinized cysts (epidermoid cyst, $n=6, O K, n=64$ OOC, $\mathrm{n}=5$ ) were diagnosed in our laboratory. Thus, OOC accounted for approximately $3.4 \%$ of all oral lesions diagnosed to date. This percentage indicates that this lesion is an uncommon entity. Nevertheless, OOC should be considered in the differential diagnosis of lesions occurring in the jawbones associated with an impacted tooth, particularly those cases simulating dentigerous cyst. 
1. Da Silva MJ, de Sousa SO, Corrêa L, Carvalhosa AA, De Araújo VC. Immunohistochemical study of the orthokeratinized odontogenic cyst: a comparison with the odontogenic keratocyst. Oral Surg Oral Med Oral Pathol Oral Radiol Endod 2002;94:732-7.

2. Li TJ, Kitano M, Chen XM, Itoh T, Kawashima K, Sugihara K, Nozoe E, Mimura T. Orthokeratinized odontogenic cyst: a clinicopathological and immunocytochemical study of 15 cases. Histopathology 1998;32:242-51.

3. Vuhahula E, Nikai H, ljuhin N, Ogawa I, Takata T, Koseki T, Tanimoto K. Jaw cysts with orthokeratinization: analysis of 12 cases. J Oral Pathol Med 1993; 22:35-40.

4. Rangiani A, Motahhary P. Evaluation of bax and bcl-2 expression in odontogenic keratocysts and orthokeratinized odontogenic cysts: A comparison of two cysts. Oral Oncol 2009;45:41-4.

5. Fregnani ER, da Cruz Perez DE, Soares FA, Alves FA. Synchronous ameloblastoma and orthokeratinized odontogenic cyst of the mandible. J Oral Pathol Med 2006 35:573-5.

6. González-Alva P, Tanaka A, Oku Y, Yoshizawa D, Itoh S, Sakashita H ET AL. Keratocystic odontogenic tumor: a retrospective study of 183 cases. J Oral Sci 2008;50:205-12.

7. Thosaporn W, lamaroon A, Pongsiriwet S, Ng KH. A comparative study of epithelial cell proliferation between the odontogenic keratocyst, orthokeratinized odontogenic cyst, dentigerous cyst, and ameloblastoma. Oral Dis 2004;10:22-6.

8. Madras J, Lapointe H. Keratocystic odontogenic tumour: reclassification of the odontogenic keratocyst from cyst to tumour. J Can Dent Assoc 2008;74:165-165h.

9. World Health Organization Classification of Tumours. Pathology and genetics of head and neck tumours. Lyon: IARC Press; 2005.

10. Onuki M, Saito A, Hosokawa S, Ohnuki T, Hayakawa H, Seta S, Muramatsu T, Furusawa M. A case of orthokeratinized odontogenic cyst suspected to be a radicular cyst. Bull Tokyo Dent Coll 2009;50:31-5.

11. Dong Q, Pan S, Sun LS, Li TJ. Orthokeratinized odontogenic cyst: a clinicopathologic study of 61 cases. Arch Pathol Lab Med 2010;134:271-5.

12. Buyukkurt MC, Omezli MM, Miloglu $O$. Dentigerous cyst associated with an ectopic tooth in the maxillary sinus: a report of 3 cases and review of the literature. Oral Surg Oral Med Oral Pathol Oral Radiol Endod 2010;109:67-71.

13. Ide F, Saito I, Horie N, Shimoyama T. Orthokeratinized odontogenic cyst of the mandible with heterotopic cartilage. Head Neck Pathol 2009;3:150-52.

14. Puricelli E. Panorametry: suggestion of a method for mandibular measurements on panoramic radiographs. Head Face Med 2009;5:19.

15. Bondemark L, Jeppsson M, Lindh-Ingildsen L, Rangne K. Incidental findings of pathology and abnormality in pretreatment orthodontic panoramic radiographs. Angle Orthod 2006;76:98-102. 